\title{
A LIBERALISED SOUTH AFRICAN AIRLINE INDUSTRY: MEASURING AIRLINE TOTAL-FACTOR PRODUCTIVITY
}

\author{
ANTON BRITS \\ britsa@unisa.ac.za \\ Department of Transport Economics, Logistics and Tourism \\ University of South Africa \\ South Africa
}

\begin{abstract}
The liberalisation of the South African airline industry through economic deregulation established competitive domestic and international markets. Sustainability of air transport, subject to these liberalisation effects, depends on efficient management information such as total-factor productivity, which necessitates comprehensive financial and operational information. Total-factor productivity in general, however, is not utilised by airlines as a key performance indicator since the measuring thereof is complex and regarded as tedious. Changes in air transport total-factor productivity can be measured in two ways. First, an index approach can be adopted that shows the proportional change in the inputs in relation to a proportional change in output. Secondly, a production function can be determined (econometric approach) that shows a change of productivity as a shift in the production curve. The research on which the article is based, exploited the theory, selection and application of an appropriate approach to determine changes of total-factor productivity of an individual airline to assist/support efficient decisionmaking by management.
\end{abstract}

\section{INTRODUCTION}

The United States Airline Deregulation Act of 1978 paved the way globally for the economic deregulation of the airline industry. Senator Edward Kennedy, as chairperson of the subcommittee for political reform in the United States, concluded back in the early 70s already that, inter alia, the deregulation of the airline industry would improve airline productivity that, which would ensure the optimum allocation of scarce air transport resources (Dempsey, 1989: 20). As such, South Africa's 'sanction-free' international commercial airline market after the election of a democratic South African government with Mr Mandela as President in April 1994 was confronted with a liberalised market environment. 'The transition to democracy opened new trade and tourism opportunities, leading to a dramatic increase in the number of airlines servicing the country, which skyrocketed from 21 in 1990 to 59 in 1998' (Goldstein, 2001: 240). The international air transport market was liberalised in terms of double designation and double disapproval modified bilateral agreements. Before 
the impact of the Airlift Strategy of 2006, South Africa had concluded bilateral air service agreements with 104 countries in all regions of the world (Department of Transport, 2006: 4). A sample of weekly flight data for four representative months (January, April, July and October) between 1994 and 2003 indicates furthermore that the number of scheduled commercial passenger flights crossing South Africa's border increased from 1935 to 4832 respectively, representing a 150\% increase (Pirie, 2006: 5). The total number of registered aircraft between 2003 (8 403) and 2007 (10 189) - i.e. commercial and non-commercial aircraft - furthermore increased by $21.25 \%$ (Civil Aviation Authority, 2008: 25).

The liberalisation of the South African airline industry was established through economic deregulation by means of the proclamation of the Air Service Licensing Act (Act No. 115 of 1990) for the domestic market, and the International Air Services Act (Act No. 60 of 1993) for the international market (Department of Transport, 2006: 3). The South African airline carrier (SAA) was readmitted as member of the International Air Transport Association and the International Civil Aviation Organisation. Cognisance had then to be taken of the fact that the international air transport market was confronted with route reconfigurations, deregulation, mergers and alliances. The probability of competitive international as well as domestic air transport markets was rife. A study by Dobruszkes (2009: 39) of the liberalisation of air transport in Europe concluded that competition as a result 'has certainly increased, but much less rapidly than the number of new routes operated by a single airline'. In African countries other than South Africa, such as Nigeria and Zimbabwe, changes have been slow because 'despite protective policies, small, un-restructured African air services have been vulnerable to global and local (sometimes franchised) competition' (Pirie, 2006: 3).

Airlines are subject to dynamic short-term market environments such as the global economic bear market experienced between the second quarter of 2008 and the first quarter of 2009. As such, after the poor economic conditions of the United States during 2000 and the September 11 terrorist attack, 'the pressure from competition, deregulated market forces, the decline of average yields per passenger and, in certain regions, the challenge from low-cost airlines, has presented management with the problem of how to improve airline economic performance' (Francis, Humphreys \& Fry, 2005: 207). Commercial performance data are essential to enable the management of an airline to react to market changes. Francis et al. (2005: 208) however found that 'little academic work has been undertaken as to the exact way information is used. This is due in no small part to the commercial sensitivity of such information'. Furthermore, the measuring of the financial performances of airlines tends to be the preferred performance evaluator and benchmarks are established accordingly (Feng \& Wang, 2000; Francis et al., 2005).

Kahn (2002) stated that the improvement of United States airline productivity was one of the major accomplishments of economic deregulation of the industry. 
Deregulation fostered this improvement by removing the previous detailed restrictions on airline prices and on where they can fly. Decontrol of prices allowed airlines to fill their planes by offering large numbers of heavily discounted fares for seats that would otherwise go unused. Decontrol of routes permitted them to plan their operations as they see fit. And deregulation has compelled improvements in efficiency through the intense pressures of the price competition it unleashed.

It is, however, questionable whether these improvements can relate to total-factor productivity since the effect of an aspect such as 'airlines fill their planes with discounted fares for seats that would otherwise go unused' may rather be attributed to economies of density. These air-transport productivity views of Kahn, who may be regarded as 'the socalled father of deregulation' (Gialloreto, 1988: 2), focus mainly on partial productivity, and underline the necessity for an accurate measuring of total-factor productivity for efficient management purposes.

Total-factor productivity measures the productivity of all inputs necessary for the production of services and therefore the cost-effectiveness (technical output) and cost-efficiency (service output). Total-factor productivity 'aggregates outputs on the basis of their revenue contribution, and inputs on their relative importance to total cost in order to calculate the overall productivity as a function of these quantities' (Vasigh \& Fleming, 2005: 9).

\section{RESEARCH STRATEGY}

The objective of the research being reported here was to provide guidelines for measuring total-factor productivity of an individual South African airline in order to manage such an airline efficiently in a liberalised air transport market environment. It was not the intention to measure the total-factor productivity of the South African air transport industry or to compare the total-factor productivity of the different airlines operating in South Africa. Guidelines for measuring total-factor productivity of an individual airline were developed by means of interrogating, arguing, and considering conclusions based on mathematical economic theories and econometric principles. An application of this measurement was illustrated with actual relevant time series data. A comparison of timely individual airline total-factor productivity differences should assist the management of such an airline with strategic planning processes and the optimum allocation of scarce economic resources.

A literature study was undertaken to research the theoretical aspects of total-factor productivity, the different measuring techniques of total-factor productivity and related global studies. Based on this research, guidelines for measuring a change in total-factor productivity of an individual airline were reasoned and constituted. Monthly data of five financial years of an individual airline were captured and used. Consequently, the totalfactor productivity changes of an individual airline, based on the guidelines and historic data, were determined. 


\section{DISCUSSION}

\section{Basis for measuring productivity}

In this article, productivity measurement refers to total-factor measuring because the productivity measurement ratios (functions), such as partial productivity, relate to the productivity of individual inputs, while main-factor productivity discounts non-factor inputs (intermediate inputs), such as fuel. A further advantage of the total-factor productivity approach is that it includes interaction between all inputs because it subsumes input substitution and any other compensating effects of air-transport inputs. Further, the reasons for productivity changes can be identified because the approach is based on the theory of cost and production functions, and so it is therefore not merely an arbitrary yardstick (Talvitie \& Obeng, 1991: 174). The essence of total-factor productivity (as the name indicates) is that the ratio takes the total value of each and every input and output of the airline into consideration, as formulated by equation 5 (page 34). Therefore, adding an Airbus 380 aircraft to a fleet of aircraft will influence the productivity of all the other aircraft in terms of service delivery/output and the inputs necessary for such service/output, and therefore the total-factor productivity of the airline as a whole.

According to the theory of cost and production, an enterprise is a basic economic unit that endeavours to maximise profit within the limits set by market conditions and the availability of technology. If the enterprise is subject to competitive market conditions, prices are determined externally and the observed transformation process (inputs to outputs) should only reflect the ratio of inputs to outputs. What is important about this ratio, however, is the influence of the input share of total cost, the output share of total cost, the possibility of substitution and the scale effects on the effectiveness of the transformation process.

The output and input amounts used in the production process are respectively identified with the real product and the real-factor inputs are measured for general accounting purposes. By applying the information to quantities as well as prices, movements along the production function can be distinguished from a shift in the production function (Solow, 1957: 312-320). A shift in the production function correlates with changes in total-factor productivity.

\section{Production theory}

Total-factor productivity is defined according to the ratio between a certain index of total output and a certain index of input. An economic interpretation of this definition is obtained through the production theory, which is based on a production function characterised by constant returns to scale. This can be noted as follows:

$$
\mathrm{F}\left(Y_{1}, Y_{2}, \ldots, Y_{m} ;\left(X_{1}, X_{2}, \ldots, X_{n}\right)=0\right.
$$

where $Y=$ output

and $X=$ input. 
Changes in total-factor productivity can be identified with shifts in the production function by adding the necessary manufacturer equilibrium conditions. That is to say, all marginal rates of substitution between pairs of inputs and outputs are equal to the corresponding price ratios. The economic production theories on which changes in total-factor productivity are based are not necessarily the only possibility (i.e. production theory). The definition of shifts in a production function (equation 1) shows, for example, that the relevant production functions can be considered in isolation from the manufacturer's conditions of equilibrium, on condition that alternative practicable definitions of marginal substitution rates are applied. Changes in total-factor productivity can be integrated under these generalised conditions, however, as movements along the relevant production function (Jorgenson \& Griliches, 1967: 254). It is possible, therefore, to confuse observed productivity changes represented by shifts in the production function with movements along the production function.

The above explanation forms the basis on which a shift in production function, and therefore total-factor productivity, can be measured.

\section{Approaches to measuring total-factor productivity}

The index number and econometric approaches to measuring total-factor productivity for air transport have been identified with the aid of a literature study. Sudit and Finger (1981: 18) explain that if a single-output production system is presumed, then a linear homogeneous production function can be estimated by establishing total-factor productivity indices, or by applying an econometric approach. A production function is homogeneous if a given percentage change in every input leads to the same percentage change in the corresponding output, raised to a given power (Talley, 1988: 53). This production function is given by the following approach:

$$
Y=A(t) f\left(X_{1}, X_{2}, \ldots, X_{i}, \ldots X_{n}\right)
$$

A(t) represents the technical change. This single-output production system is based on the theory of Solow (1957) according to which shifts in the production function (technical changes) are used to interpret a productivity analysis done by isolating movement along the production function.

The index number and econometric approaches have advantages as well as disadvantages, however. The use of this approach, or any other, is mainly dependent on the envisaged objective and the availability of relevant data. A discussion of the two approaches follows.

\section{The index approach}

According to Edgeworth's (1925: 379) classical definition of an index number ('a number adapted by its variations to indicate the increase or decrease of a magnitude not susceptible to accurate measurement'), a variety of problems may arise in association with the 
development, measurement and calculation of indices. These problems are emphasised by the classical work of Fisher (1922: 14) in which 134 different formulas were used to calculate various types of indices.

Mathematical requirements that index formulas have to comply with include the timeinversion, factor-inversion and circle tests. The time-inversion test requires that the formula used to determine an index number must be such that it reflects the same relationship between one period or place and another period or place regardless of which of the periods or places is used as the premise. The factor-inversion test is similar to the time-inversion test. An index formula is compliant with the factor-inversion test if the interchangeability of price and quantities produces non-contradictory results for all periods and places to which a set of index values is applicable. See Fisher (1922: 62-82; 270-96) for a detailed discussion of these tests.

A discussion of the application of the various indices is necessary in light of the above and the fact that alternative index formulas (such as the Laspeyres and the Paasche formulas) can yield different results.

The Laspeyres and Paasche indices are examples of a cumulative approach. They differ in that the former proceeds from the base year and the latter from the current year. Both are attended by substitution problems, however, that cause biased results. For example, a Laspeyres index (assuming a negative price-quality ratio) will overestimate a real cost-ofliving index because if an increase in consumer satisfaction or the practical benefit arising from the substitution above is applied to homothetic production function, then the Laspeyres index represents the lower and the Paasche index the upper limit of a 'reliable production index' (Sato, 1976: 441). A production function is homothetic if the relationship between two inputs, such as labour and capital, depends only on the marginal rate of technical substitution of the said two inputs - in which case factors such as output levels and service levels will have no bearing on the relationship between inputs (Talley, 1988: 52).

It is clear from the above that the ideal or 'reliable' index has to settle on a value between the Laspeyres and Paasche indices. Consequently, Fisher (1922: 169) developed an index considered ideal by index researchers. The Fisher index is the geometric mean of the Laspeyres and Paasche indices; hence, it assumes a value between the values of these two indices. The Fisher index fails the circle test, however, which can be considered optional for economic purposes (Allen, 1975: 44-47). The circle test demands non-contrary results between all periods and places on which a set of index values is applicable.

The substitution problem can be overcome by changing the basis of the index at regular intervals. The chain index is used for this purpose. For example, a yearly index or 'chain' is determined for a comparison between say 2000 and 2005 . The yearly index is obtained 
by comparing 2001 with 2000, 2002 with 2001, 2003 with 2002, and so on. The final comparison between 2005 and 2000 is made by combining the yearly indices of this period. An important feature of a chain index is that it complies with both the inversion and the circle test regardless of the type of index used to determine the underlying individual indices (Frisch, 1936: 7).

The chain index has won considerable support as a natural discrete approach to the Divisia integral, which was originally proposed by Divisia (Divisia, 1925: 980-1008). Like any other index, a Divisia index is based on prices and quantities. A Divisia price-andquantity index has a growth rate equal to the weighted average growth rate of the various quantity components and of the various prices of components. The weight in each of the above cases is the relative value of each component as a proportion of the overall value. Consequently, the Divisia integral can be used to determine the continuous growth or decline in production.

The problem with the Divisia index, however, is its continuity characteristic. In the case of air transport, for example, observations occur at certain time intervals, which result in discrete data. Consequently, since the Divisia index can determine a growth or decline in production, a discrete deduction can be made from it so that discrete data can be brought to bear on it. This discrete deduction from the Divisia index was originally proposed by $L$ Törnqvist (Dhruvarajan \& Harris, 1978: 227) and was then named after him.

The Törnqvist index approach is generally applied in air-transport productivity studies (Dhruvarajan \& Harris, 1978; Caves, Christensen \& Tretheway, 1981; Caves, Christensen \& Tretheway, 1983; Roy \& Cofsky, 1984; Caves, Christensen, Tretheway \& Windle, 1985; Gillen, Oum \& Tretheway, 1985; Oum \& Yu, 1995; Vasigh \& Fleming, 2005; Barbot, Costa \& Sochirca, 2008).

The Törnqvist approximation is the most commonly used discrete approximation to the continuous Divisia index. Diewert (1976) has demonstrated that the Törnqvist formula can be used to aggregate quantities consistently, provided that the underlying (production) function is homogeneous.

The Törnqvist index is formulated as follows.

With regard to input $(X)$ :

$$
\Delta \ln X=\ln \left(\frac{X_{t}}{X_{t-1}}\right)=\frac{1}{2} \sum_{i}\left(k_{i t}+k_{i, t-1}\right) \ln \left(\frac{X_{i t}}{X_{i, t-1}}\right)
$$


where $k_{i t}$ is the cost proportion of the $X_{i}^{\text {th }}$ input towards total cost during the ${ }_{t}^{\text {th }}$ period.

With regard to output $(Y)$ :

$$
\Delta \ln Y=\ln \left(\frac{Y_{t}}{Y_{t-1}}\right)=\frac{1}{2} \sum_{j}\left(r_{j t}+r_{j, t-1}\right) \ln \left(\frac{Y_{j t}}{Y_{j, t-1}}\right)
$$

where $r_{j t}$ is the income proportion of the $Y_{j}$ th output forming part of the total income during the th $^{\text {th }}$ period.

The ratio of these outputs to inputs, considered in relation to different periods, indicates the change in total-factor productivity between the periods in question.

\section{The econometric approach}

Using an econometric approach to estimate total-factor productivity implies the use of statistical estimation techniques. For statistical purposes it is essential, where a production function such as equation 2 is concerned, of which the values can be estimated, say by applying the least square method, to take account of all relevant factors systematically. For example, the correct econometric specification of the technological structure calls for a distinction between included and excluded technological change, and also between scalerelated and scale-unrelated technological change. The reason for this requirement is that, if the properties of the technology are not clearly expressed, the economic and statistical significance and reliability will be in doubt. These statistical requirements may cause problems (albeit more on macro- than on micro-level) because it is not always possible to determine a comprehensive specification of all system variables, as well as complete characteristics and the nature of technological change. Consequently, an estimate of aggregated production functions may yield dubious production parameters.

If the above-mentioned problems that may attend the determination of total-factor productivity can be overcome, the econometric approach (to a cost function) has the advantage of providing clarity about such matters as the status of economies of scale, economies of density, the effect of factor substitution and partial productivity in the production process. Econometric estimates have the further advantage of coping effectively with multiple inputs and outputs with the aid of a variety of statistical estimation techniques, such as factor analysis and key-component analysis. Since accounting data are readily available in commonly accessible monetary terms, it may be better at times to estimate a cost function rather than a production function. The connection between a production function and cost function is found by applying the dual theory. (See Uzawa, 1963; Shephard, 1970; Fuss \& McFadden, 1978 for a discussion of the dual theory.)

\section{Production functions}

A variety of algebraic forms can be used to represent production functions. Probably the commonest of these is the Cobb-Douglas production function (Cobb \& Douglas, 1928: 
139-65), a log-linear function, which has certain limitations, however. While more flexible functions, such as the constant elasticity of substitution (CES) are represented in general cost literature (Fuss \& McFadden, 1978: 219-268), the translog cost function is most commonly used in air-transport studies.

\section{The translog production function}

In both the Cobb-Douglas and the CES functions the scale elasticity is given. It follows accordingly that the long-term average-cost curve does not assume the U-shape that is normally accepted in the economic theory of enterprise, which brings about a long-term average-cost curve that rises continuously, or which proceeds horizontally, or declines continuously. As a result Christensen, Jorgensen and Lau (1973: 28-45) developed the translog production function.

In principle, a logarithmic function can be derived from any 'normal' (algebraic) production function, because any point in $v 1$ and $v 2$ distribution can be reflected in the log $v 1, \log$ v2 distribution; thus for any algebraic function there must be a logarithmic version. The translog cost function is composed in the same way as the translog production function, but in terms of costs and prices instead of quantities. The translog cost function is restricted to the homogeneity of the first degree where prices are concerned, since a doubling in prices, with unaltered quantities, doubles the costs.

The translog cost function has the following characteristics:

- It is flexible in the sense that it serves as a second-order approach to arbitrary production functions.

- It is a non-homothetic cost function, which means that the relationship according to which inputs are utilised depends not only on the marginal rate of technical substitution of inputs, but also on the level of service delivery.

- The elasticity of the substitution of inputs is not limited to specific values, such as zero or one, but may vary.

The translog function has certain advantages, but the change in the ratio of input to output as expressed by the production/cost function for a specific period must be observed with a view to determining total-factor productivity. This change entails the inclusion of a variable, namely time, in the relevant production/cost function.

Total-factor productivity (TFP(t)) can therefore be represented as follows:

$$
T F P(t)=\frac{Y_{t}}{Y(t)}-\frac{X_{t}}{X(t)}
$$


where $Y(t)$ and $X(t)$ respectively represent an index of aggregated outputs and inputs, and $Y t$ and $X t$ are respectively the time derivates of $Y(t)$ and $X(t)$. However, since data may only be available over discrete periods, the derivates are replaced by finite differences in the above equation of total-factor productivity.

\section{Determining total-factor productivity of an individual South African airline}

Air transport total-factor productivity studies distinguish between the index and econometric approach applied. The choice of a specific approach, or a combination of approaches, will depend on the circumstances and purpose of the research. As such, the index approach is ideal for determining the total-factor productivity of individual airlines since only timeseries data are available and therefore the number of observations is limited. The latter can be problematic for the econometric approach since such limited data may be questionable in terms of statistical significance. In general, total-factor productivity studies focus on the differences between the airlines of an airline industry of a country, or region, such as the United States of America and Europe (Oum \& Yu, 1995; Fare, Grosskopf \& Sickles, 2007; Barbot et al., 2008; Bhadra, 2009). The magnitude of these industries provides sufficient data since a product of cross-section and time-series data is available and therefore statistically significant.

The South African airline industry is relatively small and is dominated by South African Airways.

Seven major domestic airlines operate in the country, as well as a number of smaller charter airline companies. South African Airways, South African Express and Airlink fly between all the major cities and to some of the smaller ones. Kulula.com, 1time and Mango are low-cost carriers and offer flights on the more popular routes, between Johannesburg, Durban, Cape Town, Port Elizabeth, Nelspruit and George. British Airways, operated by Comair, operates flights between the major centres (SouthAfrica.info, 2009).

Cross-sectional data are limited and sensitive, and therefore a comparison of airline totalfactor productivities, or determination of the total-factor productivity of an individual airline, based on the econometric approach will be statistically insignificant. A total-factor productivity index approach will however be relevant in determining the total-factor productivity of an individual airline - and the outcome should be used to endorse an airline's management strategic decision-making process under the South African liberalisation market circumstances rather than comparing airline productivities. A discrete proportional change in total-factor productivity of an individual airline using the index approach is therefore calculated. 
The relationship between input and output as applicable in terms of production effectiveness, service efficiency and cost efficiency is shown in Figure 1. First, production effectiveness is the relationship between services outputs produced, such as seat-kilometre or production hours, and the inputs, namely, labour, capital, jet fuel and material (inputs other than labour, capital and jet fuel) are used to produce these outputs. A change in production effectiveness indicates how productively input is utilised to produce service outputs. Secondly, service efficiency, defined as how well pre-determined objectives are achieved, is the relationship between produced outputs or supply in terms of seat-kilometre, and the utilisation thereof or the demand therefor, in terms of passenger-kilometre. Thirdly, cost efficiency relates to the optimum combination of inputs to produce service output. The latter also includes economic principles and, if a government enterprise is involved, social principles may also play a role.

Output in terms of service utilisation was used to determine a discrete proportional change in total-factor productivity of an individual airline, and is represented by passenger-kilometre, freight-kilometre and mail-kilometre. These measures represent the total output production process.

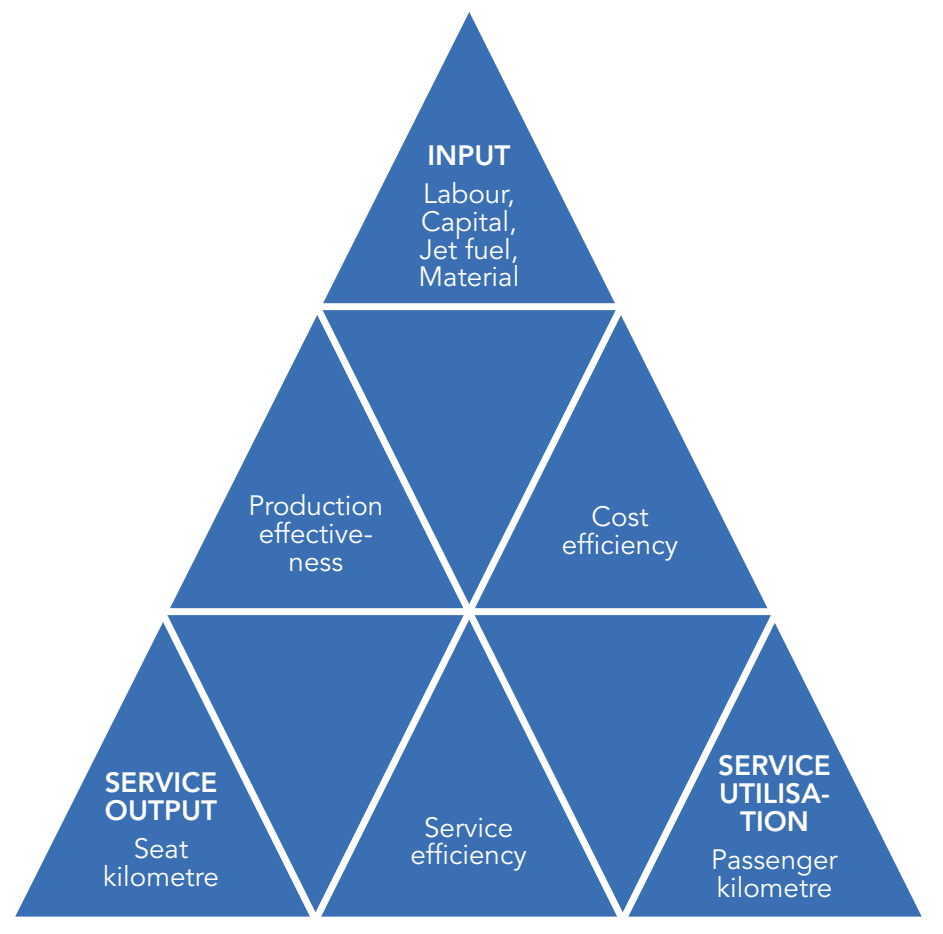

Figure 1: Framework of measurement

Labour, capital, jet fuel and material (intermediary inputs) were chosen as production inputs. The cost share of each input was used as a cost-weight when applying the approximate Törnqvist index to determine total-factor productivity. The prerequisite was however that the individual weights of the different production inputs sum to one, and the influence of technology change is included. A basis year for reference purposes is necessary to compare 
results from different periods. This basis reference should be carefully selected and should preferably be an economically stable basis year.

Monthly financial and operational data of five financial years were obtained from the data bases and archives of an individual South African airline, and allocated according to the different input and output categories. The specific five-year period was chosen because the data available were comparable. Thereafter, the internal method of data reporting by the airline was revised.

The input costs were comprehensively recorded to determine the cost share of each input as a total-factor productivity weight. The cost share of material, labour, jet fuel and capital cost are respectively 43.13, 21.49, 20.65 and 14.73 per cent. Depreciation, interest on capital and appreciated replacement values of assets are however unclear because of depreciation techniques used for accounting purposes, and therefore international values for leasing specific makes and models of aircraft were used to determine the capital costs of an aircraft.

The cost share of material was defined and recorded as all costs other than labour, jet fuel and capital costs. Since material is heterogenic, the quantity of material was determined by means of a price deflator. The total quantity of labour was used to determine the labour index because differentiated categories of labour quantities were unobtainable. Furthermore, the sensitivity of labour, for instance the comparative productivity of a pilot against that of a flight attendant, also represents a small percentage of labour's internal total-factor productivity changes. The cost data of jet fuel was obtained from the cost records, and the quantities used were determined by multiplying the average consumption of fuel of a specific aircraft type with the average distance flown.

The capital input represents the aircraft (approximately 85 per cent of the capital asset value) and the lease of national and regional capacity. The utility of aircraft in terms of the quantity component of the capital index was considered by multiplying the available payload of the specific aircraft type with the number of hours flown. The cost of aircraft was based on leasing values.

An aggregated output index of the individual South African airline was determined according to the passenger-ton-kilometre, freight-ton-kilometre and postage-ton-kilometre. The income share generated by each of these outputs are 84.44, 13.85 and 1.71 per cent respectively. Accordingly, it is evident that the transport of passengers is the most important output. The quantity of each output was obtained from the Traffic Scheduled Airline statements as made available to the International Air Transport Association. 
Consequently, using natural logarithms, a discrete proportional change in total-factor productivity was determined by the difference between aggregated output index (equation 4) and input index (equation 3), as follows:

$$
\Delta T F P=\left[\frac{1}{2} \sum_{j}\left(r_{j t}+r_{j, t-1}\right) \ln \left(\frac{Y_{j t}}{Y_{j, t-1}}\right)\right]-\left[\frac{1}{2} \sum_{i}\left(k_{i t}+k_{i, t-1}\right) \ln \left(\frac{X_{i t}}{X_{i, t-1}}\right)\right] \ldots
$$

The results obtained are given in Table 1.

Table I: Yearly total-factor productivity changes and growth rates

\begin{tabular}{|c|c|c|c|c|c|c|c|}
\hline $\begin{array}{c}\text { Financial } \\
\text { year }\end{array}$ & $\begin{array}{c}\text { Aggregate } \\
\text { input } \\
\text { index }\end{array}$ & $\begin{array}{c}\text { Aggregate } \\
\text { output } \\
\text { index }\end{array}$ & $\begin{array}{c}\text { Output } \\
\text { index } \\
\text { minus input } \\
\text { index }\end{array}$ & Anti In & $\begin{array}{c}\text { Total-factor } \\
\text { productivity } \\
\text { index }\end{array}$ & $\begin{array}{c}\text { Year- } \\
\text { to-year } \\
\text { percentage } \\
\text { change }\end{array}$ & $\begin{array}{c}\text { Percentage } \\
\text { change } \\
\text { from basis } \\
\text { year }\end{array}$ \\
\hline Year 2 & -0.0821 & -0.0964 & -0.01431 & 0.9857 & 100 & $\mathrm{~N} / \mathrm{A}$ & $\mathrm{N} / \mathrm{A}$ \\
\hline Year 3 & 0.00446 & 0.03938 & 0.03492 & 1.0355 & 105.046 & 5.047 & 5.047 \\
\hline Year 4 & 0.02030 & 0.04475 & 0.02445 & 1.0247 & 103.952 & -1.041 & 3.953 \\
\hline Year 5 & 0.02075 & 0.00027 & -0.0204 & 0.9797 & 99.385 & -4.395 & -0.614 \\
\hline
\end{tabular}

From Table I, the total-factor productivity change between the basis year (year 2) and year 3 is +5.047 per cent, between the basis year and year 4 is +3.953 per cent and between the basis year and year 5 is -0.614 per cent. The year-to-year total-factor productivity change is +5.047 between year 2 and year 3,-1.041 between year 3 and year 4 , and -4.395 between year 4 and year 5 .

The above results are evidence of the viability of the approximate Törnqvist index to determine total-factor productivity of an individual airline. They underline the sensitivity of the outcome total-factor productivity of an airline and the need therefore for efficient management of the airline.

\section{CONCLUSION}

In this research on measuring total-factor productivity of an individual airline, a distinction is made between the index approach and the econometric approach. The choice of the approach depends on circumstances and the relevant objective. The productive potential of an individual airline, an objective which is deemed to require the index approach, only shows whether productivity change is occurring or not, but does not account for the reasons for changes in productivity.

The index approach is subject to mathematical requirements such as time-inversion, factorinversion and circle tests. These requirements are necessary so that an index number reflects 
the same relationship between one period and another period regardless of which of the periods is used as a premise; the interchangeability of price and quantities produces noncontradictory results for all periods to which a set of index values is applicable. The Divisia index is based on prices and quantities and has a growth rate equal to the weighted average growth rate of the various quantity components and of the various prices of components. The Divisia index is however problematic in terms of its continuity characteristic since airtransport observations in this research are discrete in nature. Consequently, since the Divisia index can determine a growth or decline in production, a discrete deduction can be made from it so that discrete data can be brought to bear on it. This discrete deduction from the Divisia index was originally proposed by $L$ Törnqvist, named after him and used in this research.

The econometric approach to productivity measurement is based on the development of a cost function, in relation with the production function. The advantage of this approach is that besides determining productivity changes, the econometric approach can also be used to determine the substitution possibilities relating to the various inputs, the demand elasticity of the inputs, and the influence of technological changes on the input composition. The disadvantages of the econometric approach, however, are that sufficient comparable data are required but are not always available to determine the statistical significance of the coefficients being estimated. Moreover, the values of the coefficients may be estimated incorrectly as a result of multicollinearity, heteroscedasticity and autocorrelation.

Applying the Törnqvist index approach with data available from an individual South African airline over a period of five years is evidence of the viability of the approximate index to determine total-factor productivity of an individual airline. Ultimately, the total-factor productivity results will assist managing such an airline efficiently in a liberalised air transport market environment. 


\section{REFERENCES}

Allen, R. G. D. 1975. Index numbers in theory and practice. London: Macmillan.

Barbot, C., Costa, A. \& Sochirca, E. 2008. Airlines performance in the new market context: A comparative productivity and efficiency analysis. Journal of Air Transport Management, 14: $270-74$.

Bhadra, D. 2009. Race to the bottom or swimming upstream: Performance analysis of US airlines. Journal of Air Transport Management, 15: 227-35.

Caves, D. W., Christensen, L. R. \& Tretheway, M. W. 1981. US trunk air carriers, 1972-1977: A multilateral comparison of total-factor productivity. In T.G. Gowing \& R.E. Stevenson (eds.). Productivity measurement in regulated industries. New York: Academic Press.

Caves, D. W., Christensen, L. R. \& Tretheway, M. W. 1983. The structure of airline costs and prospects for the US airline industry under deregulation. Paper 8313. Madison: Social System Research Institute, University of Wisconsin.

Caves, D. W., Christensen, L. R., Tretheway, M. W. \& Windle, R. J. 1985. The effect of new entry on productivity growth in the US airline industry 1947-1981. Logistics and Transportation Review, 21(4): 299-335.

Christensen, L. R., Jorgensen, D. W. \& Lau, L. J. 1973. Transcendental logarithmic production frontiers. Review of Economics and Statistics, February: 28-45.

Civil Aviation Authority. 2008. Annual report RP: 150/2008. Pretoria: Government Printer.

Cobb, C. W. \& Douglas, P. H. 1928. A theory of production. American Economic Review, 18: 139-65.

Dempsey, P. S. 1989. The social and economic consequences of deregulation. New York: Quorum Books.

Department of Transport. 2006. Airlift strategy. Pretoria: Civil Aviation.

Dhruvarajan, P. S. \& Harris, R. F. 1978. A productivity study of the Canadian airline industry. Report No. 10-78-03. Plek: Canadian Transport Commission.

Diewert, W. E. 1976. Exact and superlative index numbers. Journal of Econometrics, 4: $115-45$. 
Divisia, F. 1925. L'Indice monétaire et la théorie de la monnaie. Revue d'Economie Politique, 39: 980-1008.

Dobruszkes, F. 2009. Does liberalisation of air transport imply increasing competition? Lessons from the European case. Transport Policy, 16: 29-39.

Edgeworth, F. Y. 1925. The plurality of index numbers. Economic Journal, 35: 379-388.

Fare, R., Grosskopf, S. \& Sickles, R. 2007. Productivity of US airlines after deregulation. Journal of Transport Economics and Policy, 41: 93-112.

Feng, C. \& Wang, R. 2000. Performance evaluation for airlines including the consideration of financial ratios. Journal of Air Transport Management, 6: 133-42.

Fisher, I. 1922. The making of index numbers. Boston: Houghton Mifflin.

Francis, G., Humphreys, I. \& Fry, J. 2005. The nature and prevalence of the use of performance measurement techniques by airlines. Journal of Air Transport Management, 11: 207-17.

Frisch, R. 1936. Annual survey of general economic theory: The Problem of Index Numbers. Econometrica, 4(1): 1-36.

Fuss, M. \& McFadden, D. (eds.). 1978. Production economics: A dual approach to theory and application. Volumes 1 and 2. New York: North-Holland.

Gialloreto, L. 1988. Strategic airline management. Great Britain: Pitman.

Gillen, D. W., Oum, T. H. \& Tretheway, M. W. 1985. Airline cost and performance: Implications for public and industry policies. Canada: The Centre for Transportation Studies.

Goldstein, A. 2001. Service liberalisation and regulatory reform in sub-Saharan Africa: The case of air transport. World Economy, 24(2): 221-48.

Jorgenson, D. W. \& Griliches, Z. 1967. The explanation of productivity change. Review of Economic Studies, 34: 249-83.

Kahn, A.E. 2002. Airline deregulation. Available from: http://www.econlib.org/library/Enc1/ AirlineDeregulation.html (accessed 19 October 2009).

Oum, T. \& Yu, C. 1995. A productivity comparison of the world's major airlines. Journal of Air Transport Management, 2: 181-95. 
Pirie, G. 2006. 'Africanisation' of South Africa's international air links, 1994-2003. Journal of Transport Geography, 14: 3-14.

Roy, R. \& Cofsky, D. 1984. A productivity study of Canadian air carriers. Report No. 1984/04E. Plek: Canadian Transport Commission.

Sato, K. 1976. The meaning and measurement of the real value added index. Review of Economics and Statistics, 58: 434-42.

Shephard, R. 1970. Theory of cost and production functions. Princeton: Princeton University Press.

Solow, R. M. 1957. Technical change and the aggregate production function. Review of Economic Statistics, 39: 312-20.

SouthAfrica.info. 2009. Domestic flights in South Africa. Available from: http://www. southafrica.info/travel/advice/flights.htm (accessed 2 December 2009).

Sudit, E. F. \& Finger, N. 1981. Methodological issues in aggregate productivity analysis. In N. Dogramaci \& N.R. Adam (eds.). Aggregate and industry-level productivity analyses. Boston: Martinus Nijhoff.

Talley, W. K. 1988. Transport carrier costing. New York: Gordon and Breach Science Publishers.

Talvitie, A. T. \& Obeng, K. 1991. Productivity and performance. Transportation Planning and Technology, 15: 169-76.

Uzawa, H. 1963. Production functions with constant elasticities of substitution. The Review of Economic Studies, 29: 291-99.

Vasigh, B. \& Fleming, K. 2005. A total factor productivity based structure for tactical cluster assessment: Empirical investigation in the airline industry. Journal of Air Transportation, 10(1): 3-19. 